\title{
Modulations of human placental transfer of lopinavir, ritonavir and enfuvirtide
}

\author{
Pierre-François Ceccaldi ${ }^{1,2,3^{*}}$, Laurent Mandelbrot ${ }^{3}$, Claudia Ferreira ${ }^{3}$, Robert Farinotti ${ }^{1}$, Francois Forestier ${ }^{1}$, \\ Sophie Gil ${ }^{1}$
}

From $16^{\text {th }}$ International Symposium on HIV and Emerging Infectious Diseases

Marseille, France. 24-26 March 2010

\section{Background}

Lopinavir boosted by ritonavir is one of the most prescribed HAART during pregnancy. This study used the human cotyledon-perfused model to investigate different elements (albumin concentrations, High-molecular weight antiviral (enfuvirtide, $4491 \mathrm{~g} / \mathrm{mol}$ ) and P-glycoprotein inhibitor drugs (ciclosporin, $1202 \mathrm{~g} / \mathrm{mol}$ )) that modulate its placental transfer.

\section{Methods}

Thirteen human cotyledons were perfused with different concentrations of albumin $(10,20,30,40 \mathrm{~g} / \mathrm{L})$. Ciclosporin A $(\mathrm{n}=11)$ and enfuvirtide $(\mathrm{n}=2)$ were respectively coperfused at middle time of the perfusion. Clearance index $(\mathrm{CI})$ of lopinavir and ritonavir were compared at different albumin concentrations and between control and ciclosporin or enfuvirtide phases.

\section{Results}

The CI of lopinavir was significantly lower at physiologic $(30$ and $40 \mathrm{~g} / \mathrm{L})$ albumin concentrations in control phases $(\mathrm{p}<0.0001)$. When adding ciclosporin $\mathrm{A}$ at physiological albumin concentrations, the $\mathrm{CI}$ of lopinavir increased significantly 10.3 fold $(\mathrm{p}=0.046)$ and became positive for ritonavir. The mean CI of lopinavir was $0.184 \pm 0.169$ in the control phase and $0.253 \pm 0.239$ following the addition of enfuvirtide, wich is 1.4 times higher but not statistical significant $(\mathrm{p}=0.39)$. There was no placental transfer of ritonavir at baseline and no variation after adding enfuvirtide. Even at supraphysiologic concentration, enfuvirtide did not cross the placenta.

\section{Discussion}

This study suggests that the most influent event for placental transfer of highly bound drug like lopinavir during pregnancy is the physiologic variation of serum albumin. P-glycoprotein expression on human placenta has also a role but seems to be slighty. Also the competition with another antiviral highly bound drugs like enfuvirtide (92\%) has a little but not significant effect on placental transfer of lopinavir.

\section{Author details}

'Department of Clinical Pharmacy, University Paris-Sud 11, IFR141, School of Pharmacy, Châtenay-Malabry, France. ${ }^{2}$ Department of Obstetrics and Gynecology, Beaujon Hospital, AP-HP, Clichy, France. ${ }^{3}$ Department of Obstetrics and Gynecology, Louis Mourier Hospital, AP-HP, Colombes, France.

Published: 11 May 2010

doi:10.1186/1742-4690-7-S1-P164

Cite this article as: Ceccaldi et al:: Modulations of human placental transfer of lopinavir, ritonavir and enfuvirtide. Retrovirology 2010 7(Suppl 1):P164.

* Correspondence: pfceccaldi@gmail.com

'Department of Clinical Pharmacy, University Paris-Sud 11, IFR141, School of Pharmacy, Châtenay-Malabry, France

Submit your next manuscript to BioMed Central and take full advantage of:

- Convenient online submission

- Thorough peer review

- No space constraints or color figure charges

- Immediate publication on acceptance

- Inclusion in PubMed, CAS, Scopus and Google Scholar

- Research which is freely available for redistribution

Submit your manuscript at www.biomedcentral.com/submit
Biomed Central 